\title{
Gross Margin, Gross Profit and the Price Elasticity of Demand
}

\author{
David E. Vance ${ }^{1}$ \\ ${ }^{1}$ Clinical Assistant Professor, School of Business, Rutgers University-Camden, Camden, USA \\ Correspondence: David E. Vance, Clinical Assistant Professor, School of Business, Rutgers University-Camden, \\ Camden, NJ 08102, USA. \\ Received: August 1, 2021 \\ Accepted: August 25, 2021 \\ Online Published: August 30, 2021 \\ doi:10.5430/jms.v12n3p1 \\ URL: https://doi.org/10.5430/jms.v12n3p1
}

\begin{abstract}
Low gross margin can predict failure. High gross margin increases the odds of superior profits. A company's gross margin is the weighted average gross margin of its products. The easiest way to change a company's gross margin is to focus on products with a low, zero or negative gross margin. The temptation might be to simply discontinue these products. A better alternative is to consider whether a product can be repriced to improve gross margin and gross profit.

Raising price reduces demand based on a product's price elasticity. Academic articles on price elasticity tend to employ calculus and statistics that are beyond the skill of the individuals who actually make pricing decisions. The contribution of this article it is to provide a clear, simple means of identifying a price point that maximizes product gross profit considering unit cost and the price elasticity of demand.
\end{abstract}

Keywords: pricing, gross margin, gross profit, price elasticity, profit maximization

\section{Introduction}

\subsection{The Implementation Problem}

Low gross margin can lead to underperformance or failure. Few companies adequately monitor the gross margin of individual products. A company's overall gross margin is the weighted average of its product gross margins. Therefore, products with a low, negative or zero gross margin can bring down a company's overall gross margin. The issue is whether these products should be discontinued or repriced. The repricing issue is informed by cost, a product's price elasticity and its current price.

Academic articles on price elasticity tend to employ calculus and statistics that are beyond the skill of the individuals who actually make pricing decisions. The objective of this article it is to provide a clear, simple means of identifying a price point that maximizes product gross profit.

\subsection{Gross Margin as Sign Post}

Product pricing should be an ongoing discussion within every company. Charge a price that is too high and a company loses sales. Charge a price that is too low and a company may give away profits that it could have made. Charge a price that is too low compared to the cost of goods sold and gross profit will suffer. It is often said that a company should charge whatever the market will bear. But that maxim provides little concrete guidance. The highest price that anyone will bear might result in so few unit sales that the product contributes little to either company level gross margin or gross profit.

Gross margin is one of the most critical ratios used to forecast a company's success or failure. Gross margin is the percentage of every dollar of sales left over after providing customers with products or services. Equation (1) is the equation for company-wide gross margin.

$$
\text { Gross Margin }=\frac{\text { Sales }- \text { Cost of Goods Sold }}{\text { Sales }}
$$

Equation (2) is product level gross margin.

$$
\text { Gross Margin }=\frac{\text { Price }- \text { Product Cost }}{\text { Price }}
$$


A company's overall gross margin is the weighted average product gross margin. To simplify the discussion, the term products shall hereafter mean goods as well as and services.

Few companies routinely monitor the gross margin. No company plans to lose money on every unit it sells, so initial prices are often set with some target gross margin in mind. But over time, competitive pressures may push down price and costs may rise. Both factors put pressure on the gross margin of individual products. Some years ago, Nestle analyzed its product line and found 7,000 items with zero or negative gross margin (Ball 2007).

So, a first order pricing strategy should be to analyze the gross margin of all products. A company may be shocked by what it finds.

An understandable first reaction might be to discontinue products with a zero or negative gross margin. As Michael Dell has said, "We don't tolerate businesses that don't make money" (Stewart 2005). That same philosophy must be applied to individual products. If you tolerate losses, you will get losses.

If a company has a target gross margin, a company might also consider eliminating products with a gross margin less than a quarter or a third of the target. Eliminating produces with a low, zero or negative gross margin will raise a company's weighed average gross margin and help it focus on products that make a significant contribution. Sometimes this strategy is discussed in terms of changing a company's product mix (White 2019).

Product gross margins should be reviewed at least annually. Gross margin should not be based on list prices, but on prices actually paid after considering routine discounts.

Assuring an adequate product level gross margin is not the ultimate goal. Gross margin is merely a signpost used to focus management's attention where needed. The ultimate goal is to maximize gross profit. As such, eliminating products with a low, zero or negative gross margin might not be the best option. The issue is whether products can be repriced so that they produce an adequate gross margin and gross profit.

\subsection{Price Elasticity}

The law of demand says that as price is raised, fewer units of a product will be sold. Where demand is elastic, raising price will result in so many fewer products being sold that total revenue will decline. When price is elastic, reducing price will result in so many more units being sold that total revenue will increase. Price is elastic when there are many suppliers of similar products (Byrns 1995). On the surface, the law of demand seems to indicate price should be lowered for goods with elastic demand. But revenue maximizing is not the same thing as profit maximizing.

Raising the price of products with a low, zero or negative gross margin will improve their gross margin, but it will also reduce the quantity sold. The issues are (i) how much can price be raised and (ii) is there a gross profit maximizing price?

Price elasticity of demand, $e$, is measured as the change in the quantity sold per change in price as shown in equation (3).

$$
e=\frac{\mathrm{dQ} / \mathrm{Q}}{\mathrm{dP} / \mathrm{P}}
$$

Price elasticity of demand is written in calculus notion because the change in quantity with a change in price is not linear over the whole demand curve. Price elasticity, $e$, is actually the slope of a line tangent to any selected point along the demand curve. However, introducing calculus puts pricing strategy beyond the reach of most business people. So, a simplifying assumption can be made. That assumption is that price elasticity is linear over a region around an existing price.

Equation (4) estimates the percentage of sales lost due to a price increase, where $e$ is price elasticity, $\Delta \mathrm{P}$ is the change in price stated as a percentage and $\Delta \mathrm{Q}$ is the change in quantity stated as a percentage.

$$
\Delta \mathrm{Q}=e \times \Delta \mathrm{P}
$$

Let and $\mathrm{Q}$ equal the quantity sold at the original price. Equation (5) estimates the quantity after the price increase, represented by the variable $\mathrm{Q}_{\mathrm{n}}$.

$$
\mathrm{Q}_{\mathrm{n}}=\mathrm{Q} \times(1+\Delta \mathrm{Q})
$$

Equation (6) estimates product gross profit after the price increase to $P_{n}$.

$$
\text { Gross Profit }=Q_{n} \times\left(P_{n}-\text { Product Cost }\right)
$$


Consider a money losing product, one that is priced at $\$ 100$ and costs $\$ 105$. Using equation (2), this product has a gross margin of $-5 \%((\$ 100-\$ 105) / \$ 100)$. Every unit sold would cost the company $\$ 5$. No one would do this deliberately, but such a situation might evolve over time as costs increase and competitive pressures weigh down on price.

Assume for this example, $2 \%$ of unit sales is lost for every $1 \%$ increase in price. This is expressed as a price elasticity of -2.0. Suppose 10,000 units of the product was sold in the last period.

What if price were raised $30 \%$ ? The new unit price, $P_{n}$, would be $\$ 130(130 \%$ x $\$ 100)$. The new gross margin using equation (2) would be $19.2 \%((\$ 130-\$ 105) / \$ 130)$. Using equation (4), unit sales would change by $-60 \%(-2.0 \mathrm{x}$ $30 \%)$. Using equation (5) the new unit sales, $\mathrm{Q}_{\mathrm{n}}$, would be 4,000 (10,000 x (1-60\%)).

Before repricing, this product would generate losses of $\$ 50,000((\$ 100-\$ 105) \times 10,000$ units). Using equation (6), after repricing, the product would generate gross profits of $\$ 100,000((\$ 130-\$ 105) \times 4,000)$. Of course, this is just an example. But it provides a framework for analysis.

Suppose price elasticity were -3.0. That means the quantity sold would decrease $3 \%$ for each $1 \%$ increase in price. The new price would remain $\$ 130$ and the gross margin would be unchanged at $19.2 \%$. The change in quantity, $\Delta \mathrm{Q}$, would be $-90 \%(-3.0 \times 30 \%)$. Remaining sales, $Q_{n}$, would be 1,000 units $(10,000 \times(1-90 \%))$. Gross profit would be $\$ 25,000((\$ 130-\$ 105) \times 1,000)$. This is still a dramatic improvement over a loss of $\$ 50,000$ on the product.

\subsection{Repricing Limits}

Repricing will not save every product. If costs are too high, if historical unit volumes are too low or if the price elasticity of demand is too great, there may be no way to achieve an adequate gross margin or gross profit for a particular product.

The absolute value of the change in price, $\Delta \mathrm{P}$, times the elasticity, $e$, must be much, much less than $100 \%$, as shown in equation (7) otherwise the remaining unit volume will be driven toward zero. As unit volume approaches zero, so will gross profit.

$$
\Delta \mathrm{P} \times e<100 \%
$$

If price increases are too great, the quantity calculated using equation (5) may appear to go negative. Of course, there is no such thing as a negative quantity. The simplifying assumption made above was that price elasticity can be estimated as a constant over a region around the current price. If the apparent quantity goes negative, that means the change in price has strayed beyond the relevant price elasticity region. The point, however, remains the same. If price is increased too much, quantity may drop so low that the product contributes little to a company's gross profit.

Price elasticity varies from product to product and time to time. Nevertheless, use of price elasticity can be a useful tool in developing a pricing strategy. A rough estimate of price elasticity can be gleaned from Table 1 Price Elasticity by Product Category (Eisenhauer 2009).

Table 1 . Price elasticity by product category

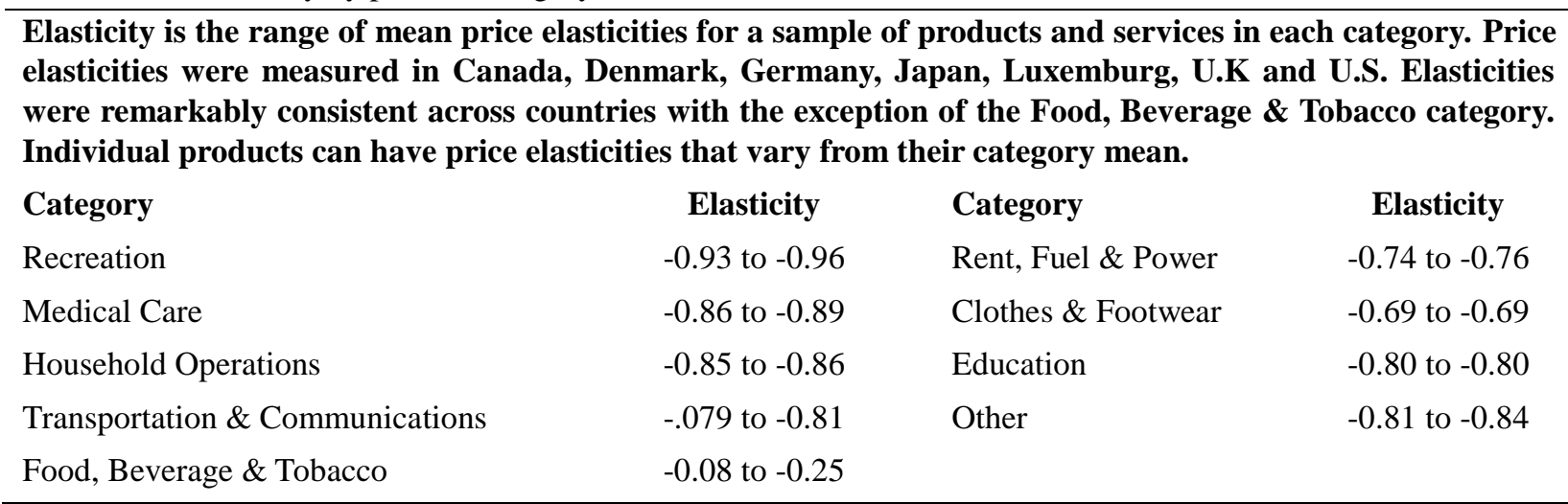

A more detailed analysis of price elasticity for selected products may be found in Appendix A Selected Price Elasticity Studies. 


\section{Method}

\subsection{Optimum Price}

Rather than resorting to calculus to find optimum price increases, the optimum price for a product can be modeled with a simple spreadsheet. The left most column should contain the percentage of price increase. The next column should use equations (4) and (5) to estimate $\mathrm{Q}_{\mathrm{n}}$, the quantity sold after the price increase. The next column should contain the expected product gross profit using equation (6). Once the table is constructed, it is a simple matter to identify the price increase that optimizes gross profit.

A high degree of price elasticity precision is not necessary to improve gross profit. A rough estimate of price elasticity is enough to move price in the right direction. If a product's estimated price elasticity is over-estimated, the quantity lost due to price increases will be overstated and gross profit will be understated. Tables 2,3 and 4 demonstrate spreadsheet models that analyze the effect of raising price for a product with an initial price of $\$ 100$ and an initial sales volume of 10,000 units using four different price elasticities.

\subsection{Negative Gross Margin Product}

Table 2 Negative Gross Margin Product, analyzes the impact on gross profit of raising the price of a product with a cost of $\$ 105$ given various price elasticities.

Table 2. Negative gross margin product

This model analyzes the impact of raising price in $5 \%$ increments. It assumes an initial product price of $\$ 100$, quantity of 10,000 , and unit cost of $\$ 105$, for an initial product gross margin of $-5 \%$. The highlighted figure is an estimate of the optimal gross profit at a given price increase and elasticity.

\begin{tabular}{|c|c|c|c|c|c|c|c|c|c|}
\hline \multirow[b]{2}{*}{ Price } & \multicolumn{3}{|c|}{$e=-3.0$} & \multicolumn{2}{|c|}{$e=-2.0$} & \multicolumn{2}{|c|}{$e=-1.5$} & \multicolumn{2}{|c|}{$e=-1.0$} \\
\hline & & & Gross & & Gross & & Gross & & Gross \\
\hline Increase & Price & Q & Profit & $\mathrm{Q}$ & Profit & Q & Profit & Q & Profit \\
\hline $0 \%$ & $\$ 100$ & 10,000 & $-\$ 50,000$ & 10,000 & $-\$ 50,000$ & 10,000 & $-\$ 50,000$ & 10,000 & $-\$ 50,000$ \\
\hline $5 \%$ & $\$ 105$ & 8,500 & $\$ 0$ & 9,000 & $\$ 0$ & 9,250 & $\$ 0$ & 9,500 & $\$ 0$ \\
\hline $10 \%$ & $\$ 110$ & 7,000 & $\$ 35,000$ & 8,000 & $\$ 40,000$ & 8,500 & $\$ 42,500$ & 9,000 & $\$ 45,000$ \\
\hline $15 \%$ & $\$ 115$ & 5,500 & $\$ 55,000$ & 7,000 & $\$ 70,000$ & 7,750 & $\$ 77,500$ & 8,500 & $\$ 85,000$ \\
\hline $20 \%$ & $\$ 120$ & 4,000 & $\$ 60,000$ & 6,000 & $\$ 90,000$ & 7,000 & $\$ 105,000$ & 8,000 & $\$ 120,000$ \\
\hline $25 \%$ & $\$ 125$ & 2,500 & $\$ 50,000$ & 5,000 & $\$ 100,000$ & 6,250 & $\$ 125,000$ & 7,500 & $\$ 150,000$ \\
\hline $30 \%$ & $\$ 130$ & 1,000 & $\$ 25,000$ & 4,000 & $\$ 100,000$ & 5,500 & $\$ 137,500$ & 7,000 & $\$ 175,000$ \\
\hline $35 \%$ & $\$ 135$ & & & 3,000 & $\$ 90,000$ & 4,750 & $\$ 142,500$ & 6,500 & $\$ 195,000$ \\
\hline $40 \%$ & $\$ 140$ & & & 2,000 & $\$ 70,000$ & 4,000 & $\$ 140,000$ & 6,000 & $\$ 210,000$ \\
\hline $45 \%$ & $\$ 145$ & & & 1,000 & $\$ 40,000$ & 3,250 & $\$ 130,000$ & 5,500 & $\$ 220,000$ \\
\hline $50 \%$ & $\$ 150$ & & & 0 & $\$ 0$ & 2,500 & $\$ 112,500$ & 5,000 & $\$ 225,000$ \\
\hline $55 \%$ & $\$ 155$ & & & & & 1,750 & $\$ 87,500$ & 4,500 & $\$ 225,000$ \\
\hline $60 \%$ & $\$ 160$ & & & & & 1,000 & $\$ 55,000$ & 4,000 & $\$ 220,000$ \\
\hline
\end{tabular}

In this example, given a price elasticity of -3.0 , the optimal price increase is about $20 \%$ and the optimal gross profit is about $\$ 60,000$. This is a significant improvement over the product's initial loss of $\$ 50,000$. Given a price elasticity of -1.0 , the optimal price increase is about $50 \%$ to $55 \%$ and the optimal gross profit is about $\$ 225,000$.

\subsection{Zero Gross Margin Product}

Table 3 Zero Gross Margin Product models the impact of raising the price of a product with a cost of $\$ 100$ and an initial gross margin of zero. 
Table 3. Zero gross margin product

\begin{tabular}{|c|c|c|c|c|c|c|c|c|c|}
\hline & & & & & 2.0 & & & & -1.0 \\
\hline Price & & & Gross & & Gross & & Gross & & Gross \\
\hline Increase & Price & Q & Profit & Q & Profit & Q & Profit & Q & Profit \\
\hline $0 \%$ & $\$ 100$ & 10,000 & $\$ 0$ & 10,000 & $\$ 0$ & 10,000 & $\$ 0$ & 10,000 & $\$ 0$ \\
\hline $5 \%$ & $\$ 105$ & 8,500 & $\$ 42,500$ & 9,000 & $\$ 45,000$ & 9,250 & $\$ 46,250$ & 9,500 & $\$ 47,500$ \\
\hline $10 \%$ & $\$ 110$ & 7,000 & $\$ 70,000$ & 8,000 & $\$ 80,000$ & 8,500 & $\$ 85,000$ & 9,000 & $\$ 90,000$ \\
\hline $15 \%$ & $\$ 115$ & 5,500 & $\$ 82,500$ & 7,000 & $\$ 105,000$ & 7,750 & $\$ 116,250$ & 8,500 & $\$ 127,500$ \\
\hline $20 \%$ & $\$ 120$ & 4,000 & $\$ 80,000$ & 6,000 & $\$ 120,000$ & 7,000 & $\$ 140,000$ & 8,000 & $\$ 160,000$ \\
\hline $25 \%$ & $\$ 125$ & 2,500 & $\$ 62,500$ & 5,000 & $\$ 125,000$ & 6,250 & $\$ 156,250$ & 7,500 & $\$ 187,500$ \\
\hline $30 \%$ & $\$ 130$ & 1,000 & $\$ 30,000$ & 4,000 & $\$ 120,000$ & 5,500 & $\$ 165,000$ & 7,000 & $\$ 210,000$ \\
\hline $35 \%$ & $\$ 135$ & & & 3,000 & $\$ 105,000$ & 4,750 & $\$ 166,250$ & 6,500 & $\$ 227,500$ \\
\hline $40 \%$ & $\$ 140$ & & & 2,000 & $\$ 80,000$ & 4,000 & $\$ 160,000$ & 6,000 & $\$ 240,000$ \\
\hline $45 \%$ & $\$ 145$ & & & 1,000 & $\$ 45,000$ & 3,250 & $\$ 146,250$ & 5,500 & $\$ 247,500$ \\
\hline $50 \%$ & $\$ 150$ & & & & & 2,500 & $\$ 125,000$ & 5,000 & $\$ 250,000$ \\
\hline $55 \%$ & $\$ 155$ & & & & & 1,750 & $\$ 96,250$ & 4,500 & $\$ 247,500$ \\
\hline $60 \%$ & $\$ 160$ & & & & & 1,000 & $\$ 60,000$ & 4,000 & $\$ 240,000$ \\
\hline
\end{tabular}

The Table 3 model indicates that products that produce no gross profit at their current price can generate significant gross profit if adequately priced even when demand is highly elastic. Given a price elasticity of -3.0 , the product generates a maximum gross profit of $\$ 82,500$ when price is increased about $15 \%$. This is a significant improvement from the product's initial gross profit of zero. Given a price elasticity of -1.0 , the maximum gross profit of about $\$ 250,000$ is reached when price is increased to about $50 \%$.

\subsection{Inadequate Gross Margin Product}

Table 4 Inadequate Gross Margin Product models a low gross margin product. Often products with low gross margins, say a quarter or a third of target gross margin, are simply discontinued. Repricing such products can often generate substantial gross profits. In this table, a product with a cost of $\$ 95$ and a gross margin of $5 \%$ is modeled.

Table 4. Inadequate gross margin product

This model analyzes the impact of raising price in $5 \%$ increments. It assumes an initial product price of $\$ 100$, quantity of 10,000, and unit cost of $\$ 95$, for an initial product gross margin of $5 \%$. The highlighted figure is an estimate of the optimal gross profit at a given price increase and elasticity.

\begin{tabular}{cccccccccc} 
& \multicolumn{3}{c}{ Price elasticity -3.0} & Price elasticity -2.0 & Price elasticity -1.5 & \multicolumn{2}{c}{ Price elasticity -1.0} \\
Price & & & Gross & & Gross & & Gross & Gross \\
Increase & Price & $\mathrm{Q}$ & Profit & $\mathrm{Q}$ & Profit & $\mathrm{Q}$ & Profit & Q & Profit \\
$0 \%$ & $\$ 100$ & 10,000 & $\$ 50,000$ & 10,000 & $\$ 50,000$ & 10,000 & $\$ 50,000$ & 10,000 & $\$ 50,000$ \\
$5 \%$ & $\$ 105$ & 8,500 & $\$ 85,000$ & 9,000 & $\$ 90,000$ & 9,250 & $\$ 92,500$ & 9,500 & $\$ 95,000$ \\
$10 \%$ & $\$ 110$ & 7,000 & $\$ 105,000$ & 8,000 & $\$ 120,000$ & 8,500 & $\$ 127,500$ & 9,000 & $\$ 135,000$ \\
$15 \%$ & $\$ 115$ & 5,500 & $\mathbf{\$ 1 1 0 , 0 0 0}$ & 7,000 & $\$ 140,000$ & 7,750 & $\$ 155,000$ & 8,500 & $\$ 170,000$ \\
$20 \%$ & $\$ 120$ & 4,000 & $\$ 100,000$ & 6,000 & $\mathbf{\$ 1 5 0 , 0 0 0}$ & 7,000 & $\$ 175,000$ & 8,000 & $\$ 200,000$ \\
\hline
\end{tabular}




\begin{tabular}{rlllrrrrrr}
\hline $25 \%$ & $\$ 125$ & 2,500 & $\$ 75,000$ & 5,000 & $\mathbf{\$ 1 5 0 , 0 0 0}$ & 6,250 & $\$ 187,500$ & 7,500 & $\$ 225,000$ \\
$30 \%$ & $\$ 130$ & 1,000 & $\$ 35,000$ & 4,000 & $\$ 140,000$ & 5,500 & $\mathbf{\$ 1 9 2 , 5 0 0}$ & 7,000 & $\$ 245,000$ \\
$35 \%$ & $\$ 135$ & & & 3,000 & $\$ 120,000$ & 4,750 & $\$ 190,000$ & 6,500 & $\$ 260,000$ \\
$40 \%$ & $\$ 140$ & & & 2,000 & $\$ 90,000$ & 4,000 & $\$ 180,000$ & 6,000 & $\$ 270,000$ \\
$45 \%$ & $\$ 145$ & & & 1,000 & $\$ 50,000$ & 3,250 & $\$ 162,500$ & 5,500 & $\mathbf{\$ 2 7 5 , 0 0 0}$ \\
$50 \%$ & $\$ 150$ & & & 0 & $\$ 0$ & 2,500 & $\$ 137,500$ & 5,000 & $\mathbf{\$ 2 7 5 , 0 0 0}$ \\
$55 \%$ & $\$ 155$ & & & & & 1,750 & $\$ 105,000$ & 4,500 & $\$ 270,000$ \\
$60 \%$ & $\$ 160$ & & & & & 1,000 & $\$ 65,000$ & 4,000 & $\$ 260,000$ \\
\hline
\end{tabular}

The Table 4 model indicates that the gross profit of a product with a low gross margin can be significantly improved even when price is highly elastic. Given a price elasticity of -3.0 , a $15 \%$ price rise increases gross profit from $\$ 50,000$ to about $\$ 110,000$. Given a price elasticity of -1.0 , a $45 \%$ to $50 \%$ price rise increases gross profit to about $\$ 275,000$.

These analyses are not an argument for raising the price of all products. They are an argument for determining whether products with a low, zero or negative gross margin can be repriced to maximize their gross profit. As with all analytical techniques, management judgment must be used to determine how and when they should be applied for any given company.

\section{Conclusion}

Many companies fail to monitor product gross margin with the result that over time some products end up with a low, zero or negative gross margin. Such products depress a company's overall gross margin which is simply the weighted average of individual product gross margins.

The temptation is to eliminate products with a low, zero or negative gross margin. But, optimizing gross margin is not the goal. Gross margin is simply a signpost that identifies products that need attention. The goal is to optimize gross profit.

Rather than eliminating products, a better strategy might be to consider raising price while recognizing the law of demand says the quantity sold will decline as price is raised. Simple spreadsheets using product cost and price elasticity can be used to estimate optimal gross profits. A high degree of precision in price elasticity is not needed to improve profits.

Pricing strategy is complicated. No article of reasonable length can hope to provide a comprehensive analysis of pricing strategy. This article is meant to focus on products with a low, zero, negative gross margin and help practitioners decide whether such products should be discontinued or repriced. If products are to be repriced, simple spreadsheet models based on product cost and price elasticity can be used to estimate the price that will yield the optimal gross profit.

\section{References}

Almon, C. (1997). A Perhaps Adequate Demand System. The Inforum Approach to Household Consumption: A Collection of Papers. College Park, MD: IERF, February.

Andreyeva, T., Long, M., \& Brownell, K. (2010, February). The Impact of Food Prices on Consumption: A Systematic Review of Research on the Price Elasticity of Demand for Food. American Journal of Public Health, 100(2), 216-222. https://doi.org/10.2105/AJPH.2008.151415

Ball, D. (2007). After Buying Binge, Nestlé Goes on a Diet. Wall Street Journal, July 23. Retrieved from https://www.wsj.com/articles/SB118515438273874597

Branch, R. E. (1993). Short run income elasticity of demand for residential electricity using consumer expenditure. Energy Journal, 14(4). https://doi.org/10.5547/ISSN0195-6574-EJ-Vol14-No4-7

Byrns, R. T., \& Stone, G. W. Jr. (1995). Economics (6th ed.). Harper Collins College Publishers. New York, NY, pp. 61-64.

Cherkin, D. C., Grothaus, L., \& Wagner, E. H. (1989). The effect of office visit copayments on preventive care services in an HMO. Inquiry, 27(1), 24-38. https://doi.org/10.1097/00005650-198907000-00001 
Dynarski, S., Li, D., \& Gruber, J. (2015). Cheaper by the Dozen: Using Sibling Discounts at Catholic Schools to Estimate the Price Elasticity of Private School Attendance. Harvard Business School Working Paper, pp. 16-054. https://www.hbs.edu/ris/Publication\%20Files/16-054_38ced934-e9b5-4a6d-9697-b906d4f27a6a.pdf

Eichner, M. J. (1998, May). The demand for medical care: What people pay does matter. American Economic Review, 88(2), 117-121.

Eisenhauer, J. G., \& Principe, K. E. (2009). Price Knowledge and Elasticity. Journal of Empirical Generalizations in Marketing $\quad$ Science, $\quad 12(2), \quad 5-7 . \quad$ Retrieved $\quad$ from https://www.empgens.com/wp-content/uploads/2009/06/EMPGENS-12-2.pdf

Espey, M. (1998). Gasoline demand revisited: an international meta-analysis of elasticities. Energy Economics, 20 , 273-295. https://doi.org/10.1016/S0140-9883(97)00013-3

Euromonitor Research. (2014). Price Elasticities in Alcoholic Drinks. Euromonitor Research. London, United Kingdom. Retrieved from https://blog.euromonitor.com/price-elasticities-in-alcoholic-drinks/

Gillingham, K., \& Tsvetanov, T. (2019, January). Hurdles and Steps: Estimating Demand for Solar Photovoltaics. Quantitative Economics, 10(1). https://doi.org/10.3982/QE919

Golder, P. N., \& Tellis, G. J. (1998). Beyond diffusion: an affordability model of the growth of new consumer durables. Journal of $\quad$ Forecasting, 17 169-346. https://doi.org/10.1002/(SICI)1099-131X(199806/07)17:3/4<259::AID-FOR696>3.0.CO;2-T

Goodwin, P., Dargay, J., \& Hanly, M. (2004, May). Elasticities of Road Traffic and Fuel Consumption with Respect to Price and Income: A Review. Transport Reviews, 24(3), 275-292. ESRC Transport Studies Unit, University College London. https://doi.org/10.1080/0144164042000181725

Green, C. E., \& Lomanno, M. V. (2012). Distribution Channel Analysis: A Guide for Hotels. HSMIA Foundation, the educational arm of the Hospitality Sales and Marketing Association, McLean, VA. p. 196. Retrieved from http://clients.theygsgroup.com/hsmai-uploads/DCAbook_Full.pdf

Henneberry, S. R., Piewthongngam, K. P., \& Qiang, H. (1999, July). Consumer Safety Concerns and Fresh Produce Consumption. Journal of Agricultural Resource Economics, 24, 98-113.

Ingraham, A. T., \& Gregory, S. J. (2004). Do States Tax Wireless Services Inefficiently? Evidence on the Price Elasticity of Demand. Virginia Tax Review, 24(2), 249-261. https://doi.org/10.2139/ssrn.525523

Jensen, B. S., \& de Boer, P. (2006). Long-Run Patterns of Demand: The Expenditure System of the CDES Indirect Utility Function-Theory and Applications. DEGIT conference paper c011-056.

Kim, K. (1998). U.S. Aggregate Demand for Clothing and Shoes, 1929-1994: Effects of Changes in Price, Nondurables Expenditures, and Demographics. Doctoral dissertation, University of Virginia.

Melnikov, O. (2000). Demand for Differentiated Durable Products: The Case of the U.S. Computer Printer Market. Working paper, Yale University, November 13.

Nelson, J. P. (2001). Hard at Play! The Growth of Recreation in Consumer Budgets, 1959-1988. Eastern Economic Journal, 27(1), 35-53.

Newhouse, J. P., \& the Insurance Experiment Group. (1993). Free for All? Lessons from the Health Insurance Experiment. Harvard University Press, Cambridge.

Prince, J. T. (2008). Repeat Purchase amid Rapid Quality Improvement: Structural Estimation of Demand for Personal Computers. Journal of Economics and Management Strategy, 17(1), 1-33. https://doi.org/10.1111/j.1530-9134.2008.00169.x

Qin, X-N. (2014). Estimating Demand for Automobile Industry in the U.S. Market 2010 - 2013. Northwestern University, Department of Economics. https://repository.library.northeastern.edu/files/neu:349589/fulltext.pdf

Revelt, D., \& Train, K. (1998, November). Mixed Logit with Repeated Choices: Households' Choices of Appliance Efficiency. Review of Economics \& Statistics, 80(4), 647-657. https://doi.org/10.1162/003465398557735

Sosewee, W. (2017). Cosmetics and Toiletries Market Growth in Economic Downturn. Feb. 12. SSRN. https://doi.org/10.2139/ssrn.2914215 
Stewart, T. A., \& O’Brien, L. (2005, March). Execution without excuses. Harvard Business Review, 83(3), 102-11, 150.

USDA. (2003). International Food Consumption Patterns. United States Department of Agriculture. Retrieved October 6, from http://www.ers.usda.gov/Data/InternationalFoodDemand/StandardReports/Priceelasticitygroups.xls

Wedig, G. J. (1988). Health status and the demand for health. Journal of Health Economics, 7, 151-163. https://doi.org/10.1016/0167-6296(88)90013-6

White, K. (2019). John West sales down but profit hike reflects margin improvements. Grocer, William Reed Business Media Ltd. Oct. 12, p. 47.

\section{Appendix A. Selected Price Elasticity Studies}

This table provides the price elasticity of demand for a selection of products. Product categories are in bold face type. Overestimating price elasticity will underestimate a product's gross profit from raising price.

\begin{tabular}{lclcllll}
\hline Apparel & $\boldsymbol{e}$ & Study & year & & $\boldsymbol{e}$ & Study & year \\
Clothes, men's & -0.80 & Kim & 1998 & Footwear & -1.12 & Jensen & 2006 \\
Clothes, women's & -0.74 & Kim & 1998 & Jewelry \& watches & -0.79 & Almon & 1997 \\
Education & & & & & & & \\
Education & -0.80 & USDA & 2003 & Catholic Schools & -0.19 & Dynarski & 2015 \\
Electronics & & & & & & & \\
Computer accessories & -0.74 & Melnikov & 2000 & Internet \& wireless & -1.29 & Ingraham & 2004 \\
Computers & -2.17 & Prince & 2008 & Telephones & -0.61 & Almon & 1997 \\
Food \& Beverage & & & & & & & \\
Alcohol, Beer, avg. & -0.51 & Euromonitor & 2014 & Fats/oils & -0.48 & Andreyeva & 2010 \\
Alcohol, Beer, dark & -1.48 & Euromonitor & 2014 & Fish & -0.50 & Andreyeva & 2010 \\
Alcohol, Brandy & -0.12 & Euromonitor & 2014 & Fruit & -0.70 & Andreyeva & 2010 \\
Alcohol, Champagne & -0.39 & Euromonitor & 2014 & Juice & -0.76 & Andreyeva & 2010 \\
Alcohol, Pre-mixed & -1.83 & Euromonitor & 2014 & Milk & -0.59 & Andreyeva & 2010 \\
Alcohol, Scotch & -0.07 & Euromonitor & 2014 & Onions & -0.11 & Henneberry & 1999 \\
Alcohol, Tequila & -1.17 & Euromonitor & 2014 & Pork & -0.72 & Andreyeva & 2010 \\
Alcohol, Vodka & -0.15 & Euromonitor & 2014 & Poultry & -0.68 & Andreyeva & 2010 \\
Beef & -0.75 & Andreyeva & 2010 & Restaurant meals & -1.42 & Jensen & 2006 \\
Carrots & -1.50 & Henneberry & 1999 & Restaurant meals & -0.81 & Andreyeva & 2010 \\
Cereals & -0.60 & Andreyeva & 2010 & Soft drinks & -0.97 & Jensen & 2006 \\
Cheese & -0.44 & Andreyeva & 2010 & Soft drinks & -0.79 & Andreyeva & 2010 \\
Cucumbers & -0.67 & Henneberry & 1999 & Sweets/sugar & -0.34 & Andreyeva & 2010 \\
Dairy & -0.65 & Andreyeva & 2010 & Tomatoes & -0.11 & Henneberry & 1999 \\
Eggs & -0.27 & Andreyeva & 2010 & Vegetables & -0.58 & Andreyeva & 2010 \\
Healthcare & & & & & & & \\
Healthcare & -0.26 & Wedig & 1988 & Healthcare & -0.20 & Newhouse & 1993 \\
Healthcare & -0.04 & Cherkin & 1989 & Healthcare & -0.69 & Eichner & 1998
\end{tabular}




\section{Household}

Clothes dryers

Cosmetics

$-0.14 \quad$ Golder

1998 Kitchen appliances

-0.40 Almon

-0.61 Sosewee

2017 Personal care

-1.28 Jensen

2006

Dishwashers

-0.42 Golder

1993 Personal goods

-1.23 Jensen

2006

Electricity

-0.20 Branch

1993 Refrigerators

-0.04 Revelt

1997

Flowers

-0.19 Almon

1997 Solar Panels

$-0.65$

Gillingham

2019

Furnishings

-0.75 Almon

1997 Tableware

-0.28 Almon

1997

Furniture

-0.41 Almon

2006 Textiles

-0.80 Jensen

2006

Glassware

-0.90 Jensen

2006 Tools

-0.19 Almon

1997

Household machines

-0.84 Jensen

1997

\section{Leisure}

Bicycles

Books

Cameras

Club Memberships

DVDs / CDs

Entertainment, live

$\begin{array}{ll}-0.07 & \text { Almon } \\ -1.35 & \text { Jensen } \\ -0.15 & \text { Almon } \\ -0.27 & \text { Almon } \\ -1.17 & \text { Nelson } \\ -0.70 & \text { Nelson } \\ -0.07 & \text { Almon }\end{array}$

1997 Hotel - economy

$-0.15$

Green

2012

2006 Hotel - luxury

$-0.50 \quad$ Green

2012

1997 Hotel - upper midscale

$-0.45$

Green

2012

1997 Leisure equipment

-1.02 Jensen

2006

2001 Radio \& Television

$-0.71$

Jensen

2006

2001 Sporting Goods

$-0.81 \quad$ Nelson

2001

Games \& Dolls

1997

Transportation

\begin{tabular}{llllllll} 
Airfare & -0.48 & Almon & 1997 & Gasoline, long term & -0.43 & Espey & 1998 \\
Volkswagen & -2.31 & Qin & 2014 & Gasoline, short term & -0.23 & Espey & 1998 \\
BMW & -4.90 & Qin & 2014 & Gasoline & -0.43 & Goodwin & 2004 \\
Ford & -2.72 & Qin & 2014 & Vehicle accessories & -0.02 & Almon & 1997 \\
Jaguar & -6.57 & Qin & 2014 & Vehicles, Other & -0.27 & Almon & 1997 \\
\hline
\end{tabular}

\section{Copyrights}

Copyright for this article is retained by the author(s), with first publication rights granted to the journal.

This is an open-access article distributed under the terms and conditions of the Creative Commons Attribution license (http://creativecommons.org/licenses/by/4.0/). 